\title{
Morphological and Histological Changes in Lungs and Thyroid Gland Due to Exposure of Formalin in Albino Rats
}

\author{
Dr Jayant Kumar Verma ${ }^{1}$, Nand Kishor Gupta ${ }^{2}$, \\ Dr N. N. Srivastav ${ }^{3}$, Dr Adil Asghar, \\ Associate Professor ${ }^{1}$, Lecturer ${ }^{2}$, Professor ${ }^{3}$, Assistant Professor ${ }^{4}$, Department of Anatomy, \\ UP Rural Institute of Medical Sciences and Research (UPUMS), Saifai, Etawah UP-206130.
}

\begin{abstract}
: formalin is used as disinfectant for preservation of museum specimens, preservation of surgical and pathology specimens, as a fumigating agent in operation theatres, for preservation of cadavers in anatomy department, in plastic industries, in dyeing and hardening of celluloid.

Formalin has many side effects because of which the importance of this study increases many times. The person working in the atmosphere of fumes of formalin may have respiratory irritation and have rhinorhoea and discharge of water from eye on direct exposure.

The present study is based on universal use of formalin in various industries including the various departments of medical sciences. The aim of study is to observe changes in Lungs and Thyroid gland in albino rats due to inhalation exposure of formalin fumes.

In this study, 100 albino rats were taken and divided into 4 groups $A, B, C$ and $D$. the group $D$ is retain as control group and the remaining 3 groups were subdivided into subgroups.

Except $D$ group rats, all other rats were exposed with Formalin for different time intervals and changes were observed, recorded and discussed in relevant headings.
\end{abstract}

Keywords: formalin, formaldehyde inhalation, rat lungs

\section{Introduction}

Formalin is $40 \%$ aqueous solution of FORMALDEHYDE which is a colorless gas having a strong, pungent and irritating odour.

It gives off vapor at room temperature. The vapors are highly pungent, respiratory irritant and produces rhinorhoea and discharge of water from eye on direct exposure. There are irritation of eyes and air passages on direct exposure. If it is swallowed it produces burning pain from mouth to stomach, nausea, vomiting, contracted pupils and flushing of face.

Lethal oral dose of formalin is 30-90 $\mathrm{ml}$ and fatal period ranges from 1-2 days.

Patient died due to formalin intake. On autopsy, shows that gastric mucosa is red, inflammed and eroded with extravasations of blood or it may be hard and tough like leather. The intestines and lungs are congested. Liver may show fatty degeneration and kidneys may be inflammed.

The present study is based on fact that the formalin is being used universally in various field. Person working in rubber industries, dyeing, all laboratory workers, all medical students, teachers and staff working in Anatomy and Pathology department remain exposed to hazardous and deleterious effect of formalin.

The aim of present study is to observe changes in lungs as well as thyroid gland due to inhalation exposure of formalin fumes.

\section{Material And Method}

In present study, 100 Albino rats have been used. Average weights of them were ranging from 100-160 gms. They were divided into 4 groups, namely A, B, C and D. The group D was retained as control. The groups A B and C were subdivided further into two subgroups as follows. In present study, sex was not considered during observation. 


\begin{tabular}{|l|l|l|l|}
\hline S.NO. & GROUPS & SUBGROUPS & NO. OF ANIMALS PER SUBGROUP \\
\hline \multirow{2}{*}{1} & $\mathrm{~A}$ & $\mathrm{~A}_{1}$ & 15 Animals \\
\cline { 3 - 4 } & & $\mathrm{A}_{2}$ & 15 Animals \\
\hline 2 & $\mathrm{~B}$ & $\mathrm{~B}_{1}$ & 15 Animals \\
\cline { 3 - 4 } & & $\mathrm{B}_{2}$ & 15 Animals \\
\hline \multirow{2}{*}{3} & $\mathrm{C}$ & $\mathrm{C}_{1}$ & 15 Animals \\
\cline { 3 - 4 } & & $\mathrm{C}_{2}$ & 15 Animals \\
\hline 4 & $\mathrm{D}$ & 10 Animals in control group. \\
\hline
\end{tabular}

Exposure

Iron case containing animal subgroups were kept in wooden boxes. These wooden boxes were having holes. Formalin was placed in a beaker in wooden box for direct inhalation exposure and holes were provided for proper aeration.

\section{Dose And Duration}

Commercial Formalin (40\% formaldehyde in water w/v) was used. $50 \mathrm{ml}$ formalin was given to each subgroup in a beaker. Formalin was changed after every 10 days. Duration of exposure in different subgroups was as follows.

\begin{tabular}{|l|l|l|}
\hline S NO & SUBGROUP & DURATION OF EXPOSURE (IN HOURS/DAY) \\
\hline 1 & $\mathrm{~A}_{1}$ & Exposed $3 \mathrm{hr} /$ day for one month \\
\hline 2 & $\mathrm{~A}_{2}$ & Exposed $6 \mathrm{hr} /$ day for one month \\
\hline 3 & $\mathrm{~B}_{1}$ & Exposed $3 \mathrm{hr} /$ day for two months \\
\hline 4 & $\mathrm{~B}_{2}$ & Exposed $6 \mathrm{hr} /$ day for two months \\
\hline 5 & $\mathrm{C}_{1}$ & Exposed $3 \mathrm{hr} /$ day for three months \\
\hline 6 & $\mathrm{C}_{2}$ & Exposed $6 \mathrm{hr} /$ day for three months \\
\hline 7 & $\mathrm{D}_{1}$ & Control group, Not exposed to formalin \\
\hline
\end{tabular}

Weight of animals of each subgroup was recorded prior to commencement and completion of experiment including the control group.

Feeding Of Animals - During experiment, rats were provided rat chow, black grams, carrot and water adlibitum. Their local hygiene was also maintained up to possible extent. Same food was also provided to control group.

Dissection Of Animals - After the completion of related period of individual animals were anaesthetized by inhalation of ether. They were sacrificed after $1^{\text {st }}, 2^{\text {nd }}$ and $3^{\text {rd }}$ month and dissected from the dorsal aspect by giving median incision and the individual organs like Lungs and Larynx (for Thyroid gland) was excised and fixed into $10 \%$ formalin for $24 \mathrm{hrs}$.

Processing - organs fixed into 10\& formalin were subjected to manual processing which consists of all step including dehydration, wax impregnation, block preparation, microtomy, dewaxing of section, staining, mounting of slides and microscopy. All necessary and precautionary steps have been taken into account. 


\section{Observations -}

Table -1 Parameter - Behavioural Changes

\begin{tabular}{|c|c|c|c|c|c|}
\hline \multicolumn{6}{|c|}{ Sub - Groups } \\
\hline A1 & A2 & B1 & B2 & C1 & $\mathrm{C2}$ \\
\hline Restlessness On & Restlessness $\quad$ On & $\begin{array}{ll}\text { Restlessness } & \text { For }\end{array}$ & Relatively & Less Restlessness & Restlessness Was \\
\hline Fresh Exposure & Fresh Exposure & About 20 Minutes & Restlessness & Respiratory & Of Lesser Degree \\
\hline For 20 Minutes & For 20 Minutes & Less Exited & Respiratory Rate & Increased & Increased \\
\hline Uncoordinated & Uncoordinated & Increased & Increased More & Sluggishly Acting & Sluggishness \\
\hline Locomotion & Locomotion & Respiratory Rate & Sluggish Behaviour & Uncoordinated & Difficulty \\
\hline Increased & Increased & Do Not Urinates & & Locomotion & Breathing \\
\hline Respiratory Rate & Respiratory Rate & On Exposure & & & \\
\hline Urinated & Urinated On Fresh & & & & \\
\hline Fress Exposure & Exposure & & & & \\
\hline & & & & & \\
\hline & & & & & \\
\hline & & & & & \\
\hline
\end{tabular}

Table -2 Parameter - General Health Changes

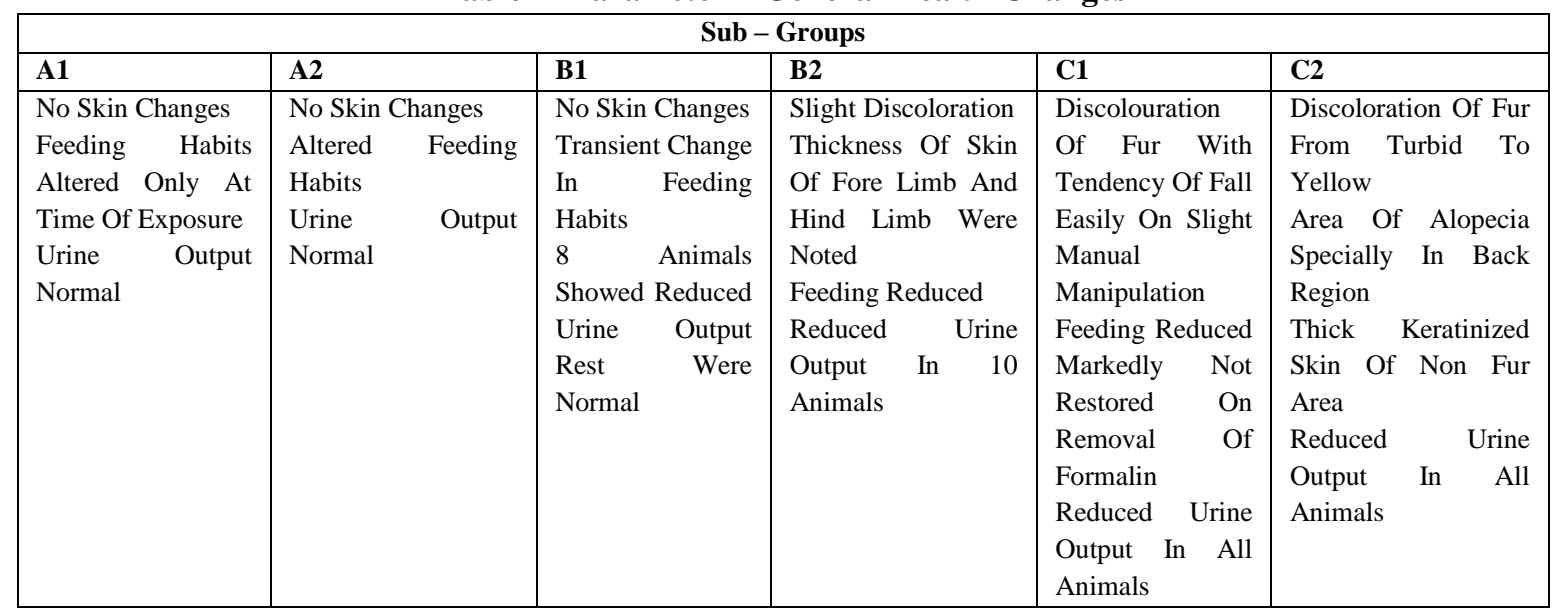

Table - 3 Parameter - Weight

\begin{tabular}{|c|c|c|c|c|c|}
\hline \multicolumn{6}{|c|}{ Sub - Groups } \\
\hline A1 & $\mathbf{A 2}$ & B1 & B2 & C1 & $\mathrm{C2}$ \\
\hline $\begin{array}{ll}\text { No } & \text { Weight } \\
\text { Loss } & \end{array}$ & $\begin{array}{l}\text { No Weight Loss } \\
\text { Recorded }\end{array}$ & $\begin{array}{l}\text { Weight Loss By } \\
\text { Gms. In Animals }\end{array}$ & $\begin{array}{l}\text { Weight Loss By } 10 \\
\text { Gms. In } 9 \text { Animals Rest } \\
6 \text { Animal Showed No } \\
\text { Weight Loss }\end{array}$ & $\begin{array}{l}\text { Weight Loss By } 15 \\
\text { Gms. In All Animals }\end{array}$ & $\begin{array}{lrr}\text { Weight } & \text { Loss } & \text { By } \\
15 \text { Gms. In } & 8 \\
\text { Animals } & \text { And } & 20 \\
\text { Gms. In } & 7 \\
\text { Animals } & & \end{array}$ \\
\hline
\end{tabular}

Table - 4 Parameter - Morphological Changes

\begin{tabular}{|c|c|c|c|c|c|c|}
\hline \multirow{2}{*}{$\begin{array}{c}\text { Morpholog } \\
\text { ical } \\
\text { Changes In } \\
\end{array}$} & \multicolumn{6}{|c|}{ Sub - Groups } \\
\hline & A1 & $\mathbf{A 2}$ & B1 & B2 & C1 & $\mathrm{C2}$ \\
\hline Lungs & Normal Morphology & $\begin{array}{l}\text { Normal } \\
\text { Morpholog } \\
\mathrm{y}\end{array}$ & $\begin{array}{l}\text { Slightly } \\
\text { Swollen } \\
\text { Lungs }\end{array}$ & $\begin{array}{l}\text { Swollen Lungs With } \\
\text { Thickened Margin } \\
\text { Decreased Elasticity } \\
\text { (Recoil Tendency) }\end{array}$ & $\begin{array}{l}\text { Swollen Lungs With } \\
\text { Thickened Margin } \\
\text { Decreased Elasticity }\end{array}$ & $\begin{array}{l}\text { Tough } \\
\text { Consistency } \\
\text { With Swollen } \\
\text { Lungs } \\
\text { Slight Loss Of } \\
\text { Spongy Nature } \\
\text { Of Lungs }\end{array}$ \\
\hline $\begin{array}{l}\text { Thyroid } \\
\text { Gland }\end{array}$ & Normal Morphology & $\begin{array}{l}\text { Normal } \\
\text { Morpholog } \\
\text { y }\end{array}$ & $\begin{array}{l}\text { Normal } \\
\text { Morphol } \\
\text { ogy }\end{array}$ & Normal Morphology & Normal Morphology & $\begin{array}{l}\text { Normal } \\
\text { Morphology }\end{array}$ \\
\hline
\end{tabular}


Table - 5 Parameter - Microscopic Changes

\begin{tabular}{|c|c|c|c|c|c|c|}
\hline $\begin{array}{c}\text { Microsco } \\
\text { pic }\end{array}$ & \multicolumn{6}{|c|}{ Sub - Groups } \\
\hline & A1 & A2 & B1 & B2 & C1 & $\mathrm{C2}$ \\
\hline Lungs & $\begin{array}{l}\text { Normal Microscopic } \\
\text { Finding } \\
\text { (Fig-1) }\end{array}$ & $\begin{array}{l}\text { Congestio } \\
\mathrm{n} \\
\text { (Fig-2) }\end{array}$ & $\begin{array}{l}\text { Congestion } \\
\text { Emphysematous } \\
\text { Lung } \\
\text { Increase In } \\
\text { Alveolar } \\
\text { Macrophage And } \\
\text { Lymphocytic } \\
\text { Infiltration } \\
\text { (Fig-3,4) }\end{array}$ & $\begin{array}{l}\text { Congestion } \\
\text { Emphysemato } \\
\text { us Lymphoid } \\
\text { Follicles } \\
\text { (Fig-5) }\end{array}$ & $\begin{array}{l}\text { Congestion } \\
\text { Emphysematous } \\
\text { In Filtration Of } \\
\text { Eosinophils, } \\
\text { Lymphocytes } \\
\text { Macrophages } \\
\text { Several } \\
\text { Lymphoid } \\
\text { Follicles Of } \\
\text { Bronchial } \\
\text { Mucosa Slightly } \\
\text { Hypertrophied } \\
\text { (Fig-6) }\end{array}$ & $\begin{array}{l}\text { Dilated } \\
\text { Emphysematous } \\
\text { Alveoli Macrophages } \\
\text { Hypertrophy Of } \\
\text { Bronchial Epithelium } \\
\text { Numerous } \\
\text { Hyperplasic } \\
\text { Lymphoid Follicles } \\
\text { Along The Bronchial } \\
\text { Wall And In Other } \\
\text { Part Of Lung } \\
\text { Parenchyma } \\
\text { (Fig-7) }\end{array}$ \\
\hline $\begin{array}{l}\text { Thyroid } \\
\text { Gland }\end{array}$ & $\begin{array}{l}\text { Normal Microscopic } \\
\text { Finding }\end{array}$ & $\begin{array}{l}\text { Normal } \\
\text { Microsco } \\
\text { pic } \\
\text { Finding }\end{array}$ & $\begin{array}{l}\text { Normal } \\
\text { Microscopic } \\
\text { Finding }\end{array}$ & $\begin{array}{l}\text { Normal } \\
\text { Microscopic } \\
\text { Finding }\end{array}$ & $\begin{array}{l}\text { Normal } \\
\text { Microscopic } \\
\text { Finding }\end{array}$ & $\begin{array}{l}\text { Normal Microscopic } \\
\text { Finding }\end{array}$ \\
\hline
\end{tabular}

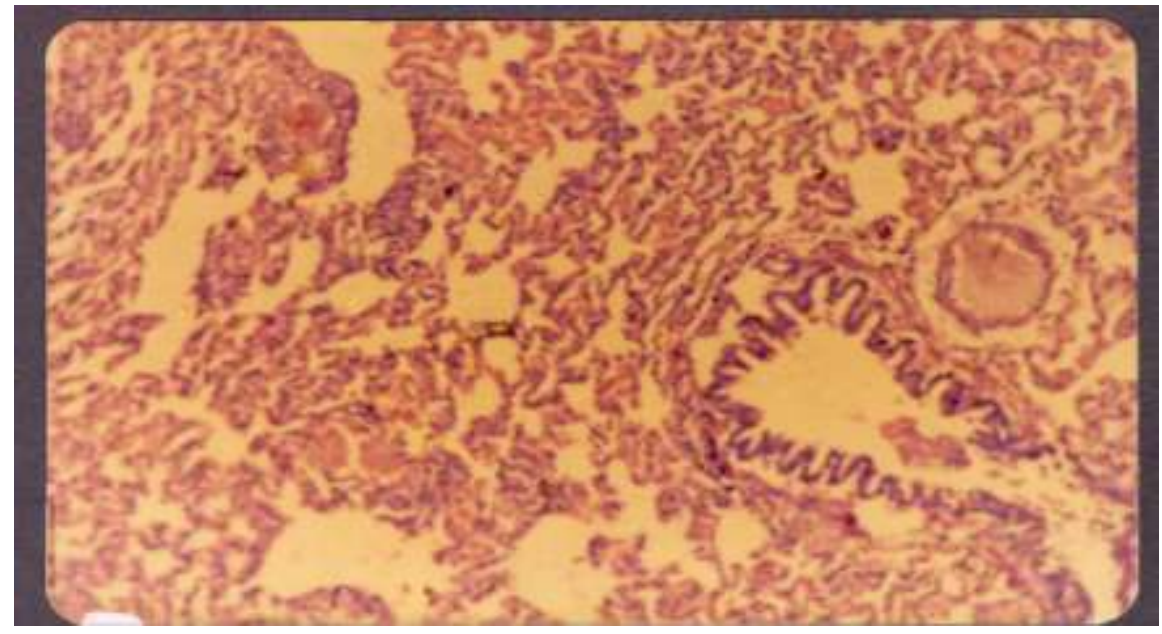

Figure 1: Normal lung showing alveioli and their wall

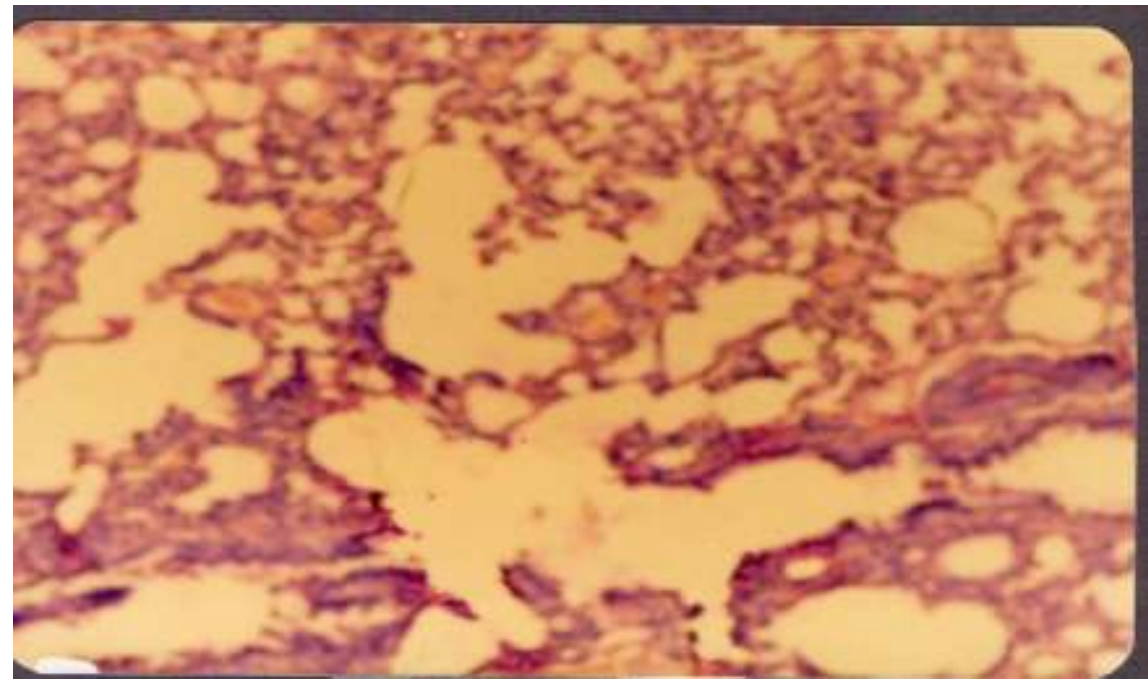

Figure 2: congestion and hyperemia 


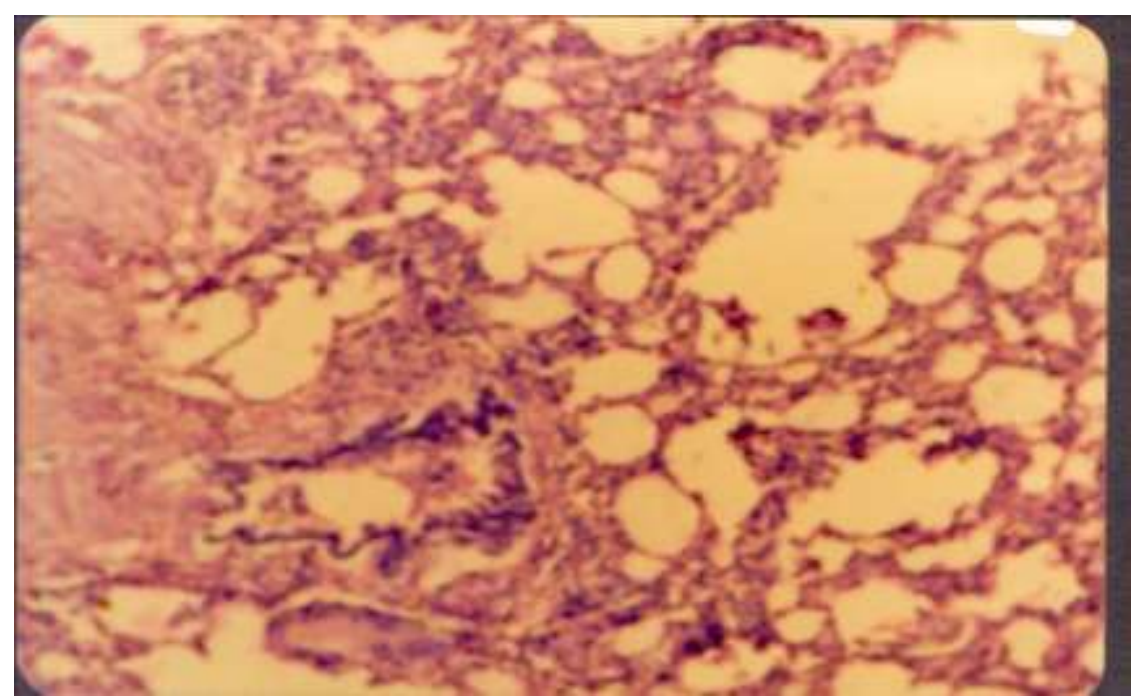

Figure3: Slight emphysematous changes with increased alveolar macrophages and congestion.

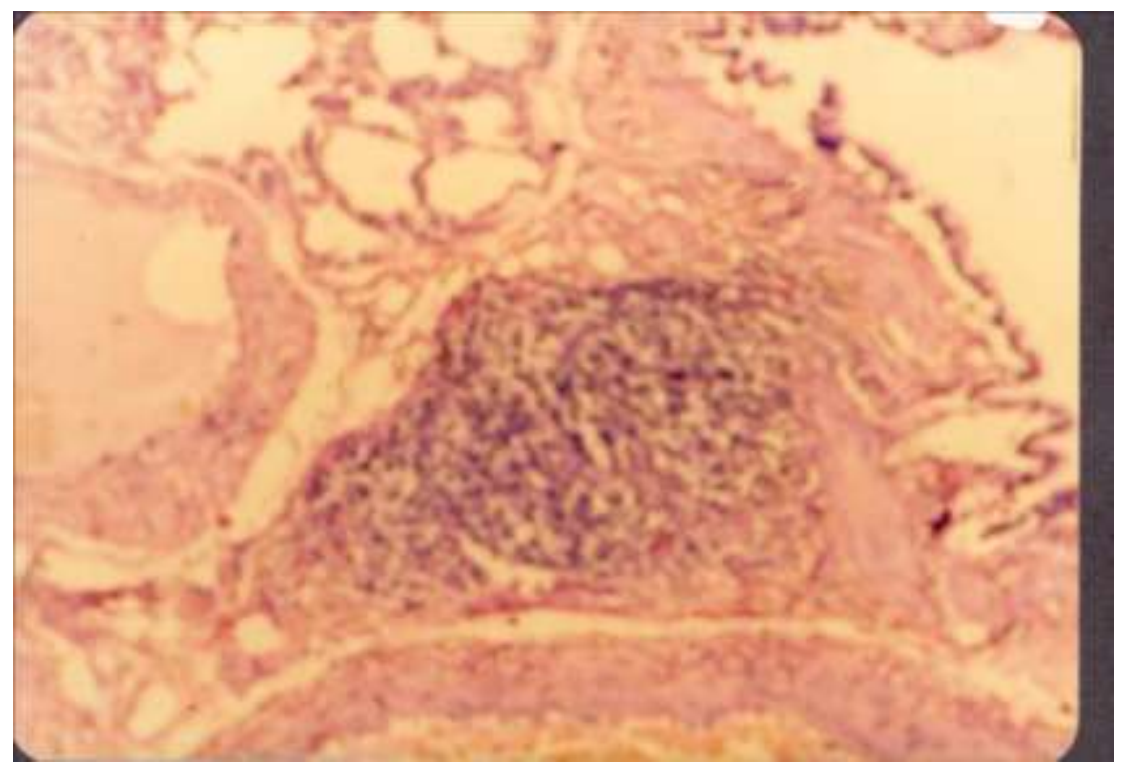

Figure 4: Congestion, emphysematous changes, lymphoid follicle

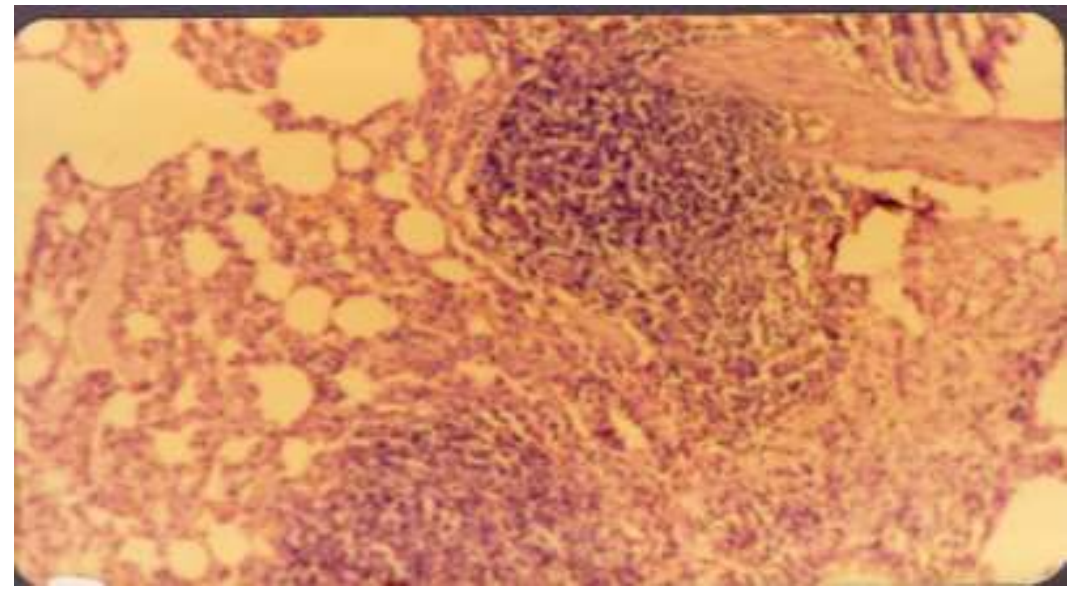

Figure 5: Many lymphoid follicles, emphysematous changes in bronchial mucosa, slightly irregular, infiltration of macrophages, lymphocytes and eosinophils 


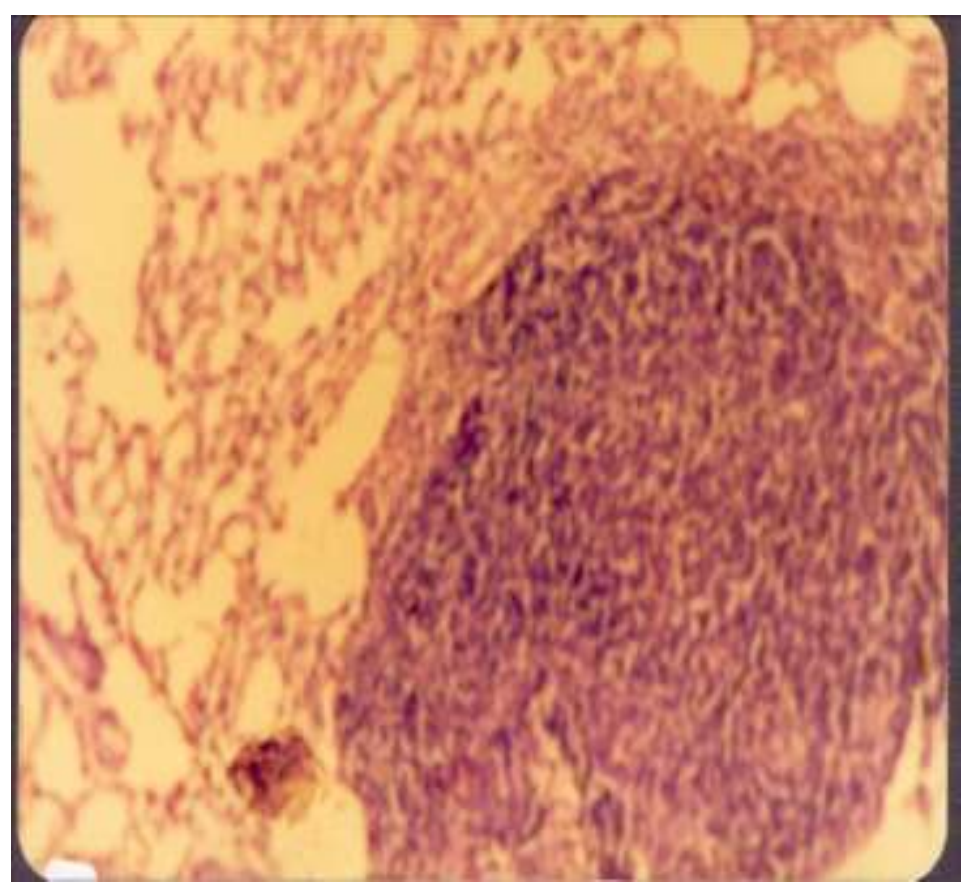

Figure6: Marked hyperplastic lymphoid follicle with increased alveolar macrophages.

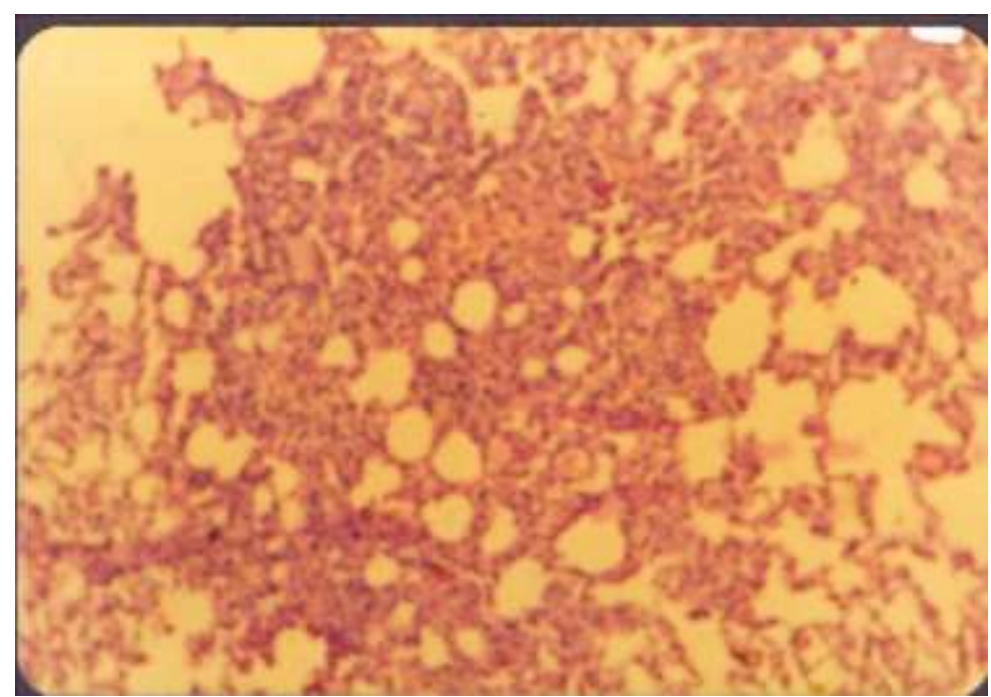

Figure 7: Interstitial pneumonia

\section{Discussion}

From preceding observations (various tables) and their comparative study with review of literature, it is evident that formalin fumes seem to be hazardous to the general health and behavioural changes to albino rats. Histology of organ shows some changes (pathology to the lesser or greater extent).

\section{Behavioural Changes:}

In present study it is evident that rest showed acute symptoms on exposure. Animal subgroups exposed for shorter duration and for lesser time period in a day (ex - subgroup A1, A2 and B1) showed restlessness on each fresh exposure of formalin for about 20 mins. The same findings were recorded by DICKSON et. al. (1987) and Wouterson et. Al . (1987)

Present study showed that animal were excited, showing increased respiratory rate and discharged urine at once on exposure and then gradually settle down. But animals exposed to longer duration (like B2, C1 and $\mathrm{C} 2$ subgroups) also showed such type of restlessness however relatively of lesser degree, but their duration of tachypnoea (increased respiratory rate) was increased and after settling they become sluggish. Similar

DOI: 10.9790/0853-1508027179 www.iosrjournals.org $\quad 76 \mid$ Page


observation has been reported by SALDIVA et. al. (1985). This paradox can be explained on the basis of environmental adaption especially animal of $\mathrm{C} 2$ subgroup. In later period of present experiment showed difficulty in breathing and some animal of C2 subgroup were extremely sluggish. WOUTERSON et. al. (1987) and TILL et. al. (1989) also observed uncoordinated locomotion and difficulty in breathing.

\section{General Health:}

Regarding general health of animals of subgroups A1, A2 and B1, there were not any significant skin changes (table 2) and feeding habit of animals were changed transiently i.e. they restored to normal on removal of formalin except that some animals showed decreased food intake during exposure but their feeding was restored to normal range on removal of formalin (A1 and A2 subgroup). There was also slight decrease in urine output in animals of B1 subgroup. Urine output in B2, C1 and C2 subgroups gradually reduced considerably.

TILL et. al. (1989) also reported a slight temporary increase in density of urine of rats. At lower doses of formalin (given in drinking water) while at higher doses oliguria was noticed.

Some skin changes were observed in B2 group table-2 which includes slight discoloration of fur and thickness of skin of fore limb and hind limb (keratinization). Aooelman et al (1988) has found adverse effect of formaldehyde in higher dose group manifested as reduced urine output, growth retardation and rhinitis changes were pronounced in animals exposed to longer duration (e.g. group C1 and C2) (Table-1). They were in the form of discoloration of fur from turbid to yellow tendency to fall of hairs easily on slight manual, manipulation (C1) and occasional area of diminished, skin was thick in non fur area and they showed significant oliguria. Woutersen et al. (1987) also observed lowered urine production in high obsess observation grouped in a study done on 140 wistar rats.

\section{Weight Loss:}

Observation on weight loss and growth retardation of animals of subgroup A1, A2 and B1 did not showed significant changes (Table-3) except about 33\% animal showed weight loss (B1). Weight loss and growth retardation was more between (5-10 gm) in animal of subgroup $\mathrm{C} 1$ and $\mathrm{C} 2$. They showed weight loss in $60 \%$ and $100 \%$ respectively. Thus, it is showing hazardous effect on general health of individual due to chronicity of exposure of formalin fumes. Aooelman et al (1988), Til et al (1989), Vorrgue et al. (1983) made the similar observation.

\section{Morphological Changes:}

Present study regarding morphological changes in different organ's showed that lungs showed slight swelling in B1 subgroup (Table-4). Decreased elasticity (recoil tendency) was observed in B2 and C1 sub-group (Table-4). The animals exposed for longer duration revealed tough consistency, rounded margins and slight loss of spongy nature of lung tissue (C2) (Table-4). The animal exposed to shorter duration showed normal morphology of lungs in comparison with control group (Table-4). These finding have not been reported by any author till now.

\section{Histological Findings:}

The histological changes in lungs were the earliest due to formalin fumes. The earliest histological findings were congestion, in A2 Sub-group animal of B1 and B2 showed congestion, emphysematous changes with appearance of lymphocytes in lungs. No. of lymphoid follicle were more in B2 Sub-group. The findings were more marked in sub-group C1 and C2 (Table-5), with infiltration of macrophages, lymphocytes and eosinophils and several lymphoid follicles. The lungs of C2 Sub-group there were dilated and emphysematous alveoli with localized pneumonitis congestion with more aggregation of eosinophils (lymphocytes + neutrophils). Follicles were also seen along the bronchial. The bronchial lining in the low dose group was insignificant while in higher dose group, there has been focal hyperplasia lining mucosa.

Gross et al (1970) showed after one month of formalin inhalation massive proliferation of alveoli, and macrophages with interstitial pneumonia.

Similarly Piment et al (1976), Avila (1971) also observed chronic interstitial fibrosis with formalin inhalation. Corrin \& Price (1972) studied the electron microscopy of lung exposed to formalin vapour and reported increase in alveoli exposed to formalin globuler cells which are found to be type II granular pneumocytes.

DOI: $10.9790 / 0853-1508027179 \quad$ www.iosrjournals.org $\quad 77 \mid$ Page


Martin (1973) showed a mixed infiltrate in the inflammatory foci comprising of macrophages, eosinophils,, neutrophils, and lymphocytes in alveola wall. Similar finding were noted in present study. Johnson \& Ward (1974) showed that neutrophil infiltration may be a response against pulmonary injury produced by formalin vapour.

Animal of sub-group A1, A2, B1 and B2 showed normal splenic histological finding. Occasional black pigmentation and congestion with normal white pulp were noted in animal (increased red pulp) (increase celularity) with slight reduction in white pulp area were noted down in C2 sub-group (Table-5) Vorgeo et al (1993) also demonstrated increased cellularity of spleen. No abnormal Histological finding observed in thyroid gland.

\section{Conclusion}

From the present study this is evident that the formalin has a definite damaging effect on general health, behavior of animals and at the histological level.

1. Behavioral changes were noted almost in all sub-groups which were indicating the acute response of animals. Besides these behavioral changes in some of the sub-group which were exposed for longer duration showed paradoxical behavior as was not expected due to exposure, indicated towards the environmental adaptation of animal up to certain extent.

2. Feeding habits were also compromised in animals of longer duration. Though weight loss was not remarkable finding but general body health like weak and yellow fur, Keratinization of skin and decreased urine output were the common presentation.

3. Morphological changes in Thyroid gland did not showed any kind of change in any sub-group.

4. Principal organ of impact were lungs. They showed changes even in animals who were exposed for shorter duration. The lung showed lymphoid hyperplasia with follicle formation with mild to moderate emphysematous changes. Parenchymal epithelium in short duration group din not showed any change while on prolong exposure occasional area of hyperplasia of bronchial lining with seen. Increase in alveolar macrophages with increased interstitial stroma is also seen in these cases. Spleen was the organ affected less and thyroid was the least.

Thus it can conclude that formalin can cause a deleterious health derangement both on acute as well as chronic exposure. The dose and duration of exposure are also important. Very higher doses over shorter duration may kill the individual. Lesser doses for longer period, may cause permanent disorganization of general health especially, respiratory function, blood gases (due to diffusion defect).

Finally the lung shows chronic pulmonary restrictive disease like pattern. In total formaldehyde (formalin) has a potential for, increased mortality and morbidity. Hence there must be adeuate precaution during it's use and some legislation are working in that atmosphere for a long period. The Brazilian legislation has considered formaldehyde (formalin) as a definite environmental pollutant and fixed its thershold limit value (TLV) up to $1.9 \mathrm{ppm}$ for $8 \mathrm{hr}$. a day for 5 days in a week.

\section{Bibliography}

[1]. Adams, D.O. (1976). The granulamatous inflammatory response. A review. Am.J. Pathol, 84 : 164-191.

[2]. Adamson, I.V.R., Bowden, D.H. (1974). The type II cells as progenitor of alveolar epithelial regenration. Lab. Invest. $30: 35$ - 42.

[3]. Aooelaman, LM, Woutersen, RA, Zwart, A., Falke, HE, Feron, VJ (1988). One year inhalational toxicity study of formadehyde in male rats with a damaged or undamaged nasal mucosa. J. Appl. Toxicol. Apr. 8 (2) : $85-90$.

[4]. Avila, R (1971). Extrinstc allergic alveolits exposed to fis meal and paultry. Clin. Allergy. $1: 343$ - 346.

[5]. Bories P et al (1985). Sclerosing Cholangitis following surgical treatment of hdatid cyst of liver. Probable role of the formal. Injection of bileducts. Gastroenterol. Clin. Biol. 1985 Feb; a (2) : $113-6$ (eng. Abstr.) (Fre).

[6]. Bruze M. et al (1985). Contact allerty to Phenol formaldehyde resins. Contact dermititis. 1985 Feb; 12 (2) : $81-6$.

[7]. Cooper P. (1979). Study of Gentic effect of formaldehyde. Food Cosmet Toxicol 1979 Jun; 17 (3) : $3001-1$.

[8]. Corrin, B. and Price, A.B. (1972). Electron microscopic studies in desquamative interstitial pneumonia, phenomena associated with asbestos. Thorax, $27: 324-331$.

[9]. Davies, P. Sornberger, G.C. and Huber, G.L. (1977). The stereology of pulmonary alveolar macrophages after prolonged experimental exposure to tabacoo smoke, Lab. Invest., 37 : 297 -306.

[10]. Dreisen, R.B., MC, Carthy, K., Zanolari, B., Hensen, P.M. (1979). Induction of chemotactic factor release from alveolar macrophage by immune complex and activated complement (Abst.) Clin. Rs., $27: 55 \mathrm{~A}$.

[11]. Dunnil, M.S. (1982). Extrinsic allergic alveolitis. In : Pulmonary Pathology. Churchill Livingston and London. Pp.113.

[12]. Gee, J.B., Godel, P.T. \& Zorn, S.K. (1978). Sarcoidosis and mononuclear phagocytes : Lung. $155: 243$ - 253. 
[13]. Golikov, P.P., Kladiev, A.A., Nikolaeva, NIU, (1989). Effect of analgin on glucocorticoid receptors of the liver. Famakol. Thoksikol. Jul-Aug; 50 (4) : 51-4.

[14]. Golikov, P.P., Kladiev, A.A., Nikolaeva, NIU, (1986). Changes in the level of glucocorticoid receptors in rat tissues on exogenous and endogenous increase in glucocorticoiid level. Vopr. Med. Khim. Jul-Aug: 32 (4) : $51-4$.

[15]. Gross, P., DE Treveilla, R.T.P. and Haller, M. (1970). Pulmonary Ferruginous bodies. Proceedings of an international conference H. Shapiro, Ed., Oxford University Press, London, pp.882.

[16]. Groten J.P.., Schoen, E.D., Van Bladeren, PJ. Nuper, C.F., Vanzorqe, J.A. Feron, VJ. (1997). Subacute toxicity of a mixture of nine chemicals in rats detecting interactive effect with a fractionated two level factorial design : Fundam. Appl, Toxicol Mar; 36 (1) : 15 -29 .

[17]. Hunnignhake, G.W., Gadek, kawanamio, Ferrans, V.J. and Crystel, G. (1979). Inflammatory and immune process in the human lung in health and disease, evaluation by bronchoalveolar lavage. Am. J. Pathol. $97: 149-206$.

[18]. Johnson, K.J. and Ward, P.F. (1974), Acute immunologic pulmonary alveolitis. J. cin. Invest., 54 : 349 - 357.

[19]. Leiden, et. Al. (1984). Absence of specific Ig E-antibody in contact sensitivity to formaldehyde.

[20]. Liebling T et. Al. (1984). Cancer mortality among workers exposed to formaldehyde. Am. J. Ind. Med. 1984; 5 (6) : 423 - 8.

[21]. Liebow, A.A. (1975). Definition and classification of interstitial pneumonia in human pathology prog. Resp.Rs. $8: 124-132$.

[22]. Malcol, A.R. et al. (1985). Effect of Ethenol, Phenol, Formaldehyde and selected metabolites on metabolic co-operation between Chinese hamaster V79 lung fibroblast. Carcino. compr. Surv. 1985; $8: 305-18$.

[23]. Martin, R.R. (1973). Altered morphology and increased acid hydrolase content of pulmonary macrophages from cigarette smoke. Am. Rev. Respire. Dis. $107: 549-560$.

[24]. Matulionis, D.H. and Trauring, H.H. (1977). In situ response of lung macrophages and hydrolase activity to cigarette smoke. : Lab. Invest. $37: 314-326$.

[25]. Pimental, J.C. (1970). Furries's lung. Thorax, $25: 387$ - 398.

[26]. Pool B.L. et al. (1984). Formaldehyde as a possible mutagenic metabolite of N-Nitrodimehylamine and of other agents which are suggested yield. Non alkylating species in vitro. Carcinogenesis 1984 Jun; 5 (6) : $809-14$.

[27]. Richet, G., Wahbe, F., Haq Eqe, J., Wiemeyer, W. (1987). Clin. Exp. Hypertens. (A) 9 suppl. $1: 127$ - 34.

[28]. Roush G.C. et al. (1987). Nasophyrangeal cancer, sinusoidal cancer and occupation related to formaldehyde a case control study. JNCI 1987 De; 79 (6) : $1221-4$.

[29]. Saldiva, P.H., DO, Rio. Caldeira, M.P., Massad, E., Calheiros, D.F., CArdose, LM., B Ohm., G.M. Saldiva, C.D. (1985). Effect of formaldehyde and acetaldehyde inhalation on rat's pulmonary mechanism. J. Appl. Toxicol. Oct : 5 (5) : $288-92$.

[30]. Schachter EN et. Al. (1987). A study of respiratory effect from exposure to 2-0 ppm. formaldehyde in occupationally exposed worker. Environ. Rs. 1987 Dec; 44 (2) : $188-205$.

[31]. Sharon R. (1979). Reduced antibody response in patient with cronic renal failure undergoing haemodialysis with formaldehyde sterilized unit. Transfusion Nov.-Dec. 19(6) : $754-5$.

[32]. Skrzydlewska, E., (1996). Decreased antioxidant status and increased lipid peroxidation in rats after methanol intoxication : Rocz. Akad. Med. Bialymst. $1996: 41$ (2) : $397-404$.

[33]. Smith, J.P., Smith J.C. and Mccal., A.J. (1960). Chronic poisoning from cadmium fumes. J. Pathol. Bacteriol, 80 : 287296.

[34]. Til, H.P., Woutersen, R.A., Feron, V.J., Hollanders, V.H., Falke, H.E., Clary, J.J. (1989). Two year drinking water study of formaldehyde in rats. Food. Chem. Txicol. Feb.-27 (2) : $77-87$.

[35]. Varqov, a.M., Wagnerov, a.J., Liskova, a., Jakubovsky. J. Gaidov, a.M., Stolcov, a.E., Kubov a.J., Tulinsk, a.J., Stenclov, a.R. (1993). Subacute immunotoxicity study of formaldehyde in male rats : Drug. Chem. Toxicol. : 16(3) : $255-75$.

[36]. Ward, P.A. (1979), Immune Complex injury of the lung. Am. J. Pathol, 97 : 97 - 91.

[37]. Woutersen, R.A., Aooelman, L.M., Wilmer, J.W., Falke, H.E., Feron, V.J. (1987). Subchronic (13 week) inhalational toxicity study of formaldehyde in rats. J. Appl. Toxicol. Feb. : 7 (1) : $43-9$.

[38]. Yoshioka, T., Yamamoto, K., Kobashi, H. Tomita, M. tsuji, T. So Liver 1994 June. : 14(3) : 129 - 37.

[39]. Yuen, T.G.H. \& Sherwin, R.P. (1971). Hyperplasia of type II pneumocytes and Nitrogen dioxide exposure. Arch. Environ. Health. $22: 178-188$. 